\title{
Location Choices of Multinational Firms: The Case of Mergers and Acquisitions
}

\author{
Olivier Bertrand \\ Toulouse School of Economics \\ Jean-Louis Mucchielli \\ University of Paris 1 Panthéon - Sorbonne \\ Habib Zitouna \\ High School of Economic and Commercial Sciences
}

\begin{abstract}
This article examines the location choices of cross-border Mergers and Acquisitions (M\&A) between OECD members' firms in the 1990's. In addition to traditional determinants of FDI, we estimate the impact of specific factors affecting the M\&A location pattern. Two distinct econometric methods are implemented: the conditional logit and the count model. We find that the supply of target firms constrains the location of $M \& A$. However, it is not the only determinant of location: the market size, the labor cost, the market access and the financial openness play a positive and significant role in the M\&A location. A bandwagon effect is also observed. In the opposite, the corporate tax rate and the productivity decrease the probability to attract $M \& A$. Cultural and geographic distances as well as differences in legal rules exert a negative significant impact on M\&A strategies too. Only the ownership structure has contrasted results.
\end{abstract}

Olivier Bertrand : GREMAQ - Université de Toulouse 1, Manufacture des Tabacs - Bâtiment F - 21 Allée de Brienne, 31000, Toulouse (France); E-mail: olivier.bertrand@univ-tlse1.fr Jean-Louis Mucchielli: TEAM - University of Paris 1 Panthéon-Sorbonne and CNRS. Maison des Sciences Economiques, 106-112, Bd de I'Hô pital - 75647 Paris Cedex 13. E-mail: jlmuc@univ-paris1.fr *Corresponding author, Habib Zitouna: CEFI-École Supérieure des Sciences Économiques et Commerciales de Tunis (Tunisia), 4, Rue Abou Zakaria El Hafsi -Montfleury 1089 -Tunis (Tunisia). Email: Habib.Zitouna@ essec.rnu.tn

@2007-Center for International Economics, Sejong Institution, All Rights Reserved. 
- JEL classification: F23, L1, R3

- Keywords: Foreign Direct Investment, Merger and Acquisition, Location, Conditional Logit, Count Model

\section{Introduction}

The 20th century witnessed a strong activity of Mergers and Acquisitions (M\&A) on several times (Scherer and Ross, 1990). However, the 1990's experienced a new wave of industrial restructuring which differed in many respects from prior consolidation periods. First, it involved larger multinational firms: the transaction value rose dramatically (Kang and Johansson, 2000). Also, M\&A took place not only in manufacturing, but also in services sectors, especially in telecommunications, financial services and business services (OECD, 2001; Evenett, 2002). Another important feature is that M\&A implied much more crossborder operations (Black, 2000): ${ }^{1}$ their number grew very quickly from 4149 in 1991 to 5373 transactions in 1998 (UNCTAD, 2000). Almost 90\% of these operations concerned developed countries' firms. Furthermore, they represented on average about one quarter of total M\&A transactions during the last decade, both in terms of value and number. Finally, they mainly consisted in horizontal restructuring (UNCTAD, 2000). In 1999, horizontal operations accounted for more than $70 \%$ of cross-border M\&A transaction value. ${ }^{2}$

Through cross-border M\&A, multinational firms strengthened their international position on foreign markets: cross-border M\&A progressively replaced Greenfield Investments in Foreign Direct Investment (FDI) over the 1990's. A Greenfield Investment is defined as the establishment of a new production facility in contrast to a cross-border M\&A where a firm purchases shares of an existing foreign firm. ${ }^{3}$ During this period, about $80 \%$ of FDI transaction value took the form of M\&A. ${ }^{4}$ Therefore, facing this major change in FDI composition, it becomes legitimate to enquiry cross-border M\&A when examining the decision of international investments.

\footnotetext{
The first four M\&A waves were mainly confined to the United States and Great Britain. The fifth and last M\&A wave encompassed all major industrial countries.

${ }^{2}$ Vertical M\&A were also in progress over the last decade, but they did not exceed $10 \%$ of total M\&A.

${ }^{3}$ Note that we will use indistinctly the terms merger and acquisition.

${ }^{4}$ Very recently, M\&A declined in comparison to Greenfield Investments. The share of cross-border M\&A deals in FDI fell from $80 \%$ in 2001 to $55 \%$ in 2002 (UNCTAD, 2003).
} 
The expansion of cross-border M\&A raises new questions: are cross-border M\&A affected by the same set of location determinants as Greeneld Investments ? Do some factors, more specific to M\&A, play a role in their location? Or, reversely, do only merging firms' characteristics matter, not really their geographic location, as some people may think? To sum up, why has a French firm more incentives to take over or to merge with a German firm rather than a British one, or conversely ? It is not clear to what extent the location decision of M\&A differs from that of Greenfield Investments or whether location aspects are important in M\&A operations. This relevant question in term of FDI policy remains almost unexplored: the literature on cross-border M\&A is still in its infant stage.

In recent years, there have been in international economics two main empirical groups of studies on FDI and their determinants. The first one is related to the theory of multinational firms in general equilibrium framework. ${ }^{5}$ It discriminates among horizontal multinational firms, vertical ones and third type of multinational firms issued of the knowledge-capital model. ${ }^{6}$ The second strand of literature more directly interests in location choices. Most of these empirical papers are closely linked to the theoretical framework of the new economy geography. ${ }^{7}$ They mainly test the ifluence of market size and agglomeration effects on firms' location decisions. ${ }^{8}$ However, these two sets of empirical works do not usually analyze M\&A explicitly. They treat only Green eld Investments or consider FDI only as Greenfield Investment, except to our knowledge O'Huallachain and Reid (1997) and Basile (2004). O'Huallachain and Reid notice that M\&A are less concentrated geographically than Greenfield Investments: the location of M\&A is restricted in given region by the scarcity of available acquisition candidates. Nevertheless, this result is mitigated by Basile in Italy at a regional level. The level of market size or labor costs play a role as important as the supply of target firms, challenging some scholarly disinterest in the distribution of acquisitions in spatial economics

${ }^{5}$ For horizontal multinational firms, see Horstmann and Markusen (1992) or Markusen and Venables (1988), for vertical multinational firms, Helpman (1984) or Zhang and Markusen (1999), and finally for the knowledge-capital model Markusen (1997).

${ }^{6}$ These theoretical models were tested in different ways. The results of these studies were not quite affirmative. However, they often found a best support for the horizontal model of multinationals (Markusen and Maskus, 1999,b; Markusen and Maskus, 2002; Blonigen et al., 2003).

${ }^{7}$ See Fujita et al. (1999) or e.g. Neary (2001) for an exhaustive overview of this theoretical field.

${ }^{8}$ See Woodward (1992), Head et al. (1995) or e.g. Mayer and Mucchielli (2002). 
(Chapman, 2003).

Compared to this literature on FDI location, other studies examined cross-border M\&A, but without tackling the issue of their location. Some authors analyzed crossborder M\&A as an entry mode. Caves and Mehra (1986) or for instance Hennart and Park (1993) explained the trade-off between M\&A and Greenfield Investment of foreign firms entering the U.S. market. Zejan (1990), then Andersson and Swensson (1996) observed Swedish overseas strategies. Baldwin and Gorecki (1987) compared these two entry modes for foreign and domestic firms in Canadian sectors. Girma (2002) assessed the influence of the European integration on the determinants of non-European companies penetrating into the United Kingdom through cross-border M\&A and Greeneld Investments.

Other studies focused exclusively on cross-border M\&A and their determinants. For instance, at a microeconomic level, Gonzalez et al. (1998) put forward the arguments of target firms' under-valuation or mismanagement. From an event study, Seth et al. (2000) found that synergy gains constituted the main motivation of cross-border M\&A. As for Louri (2001), she analyzed microeconomic factors of foreign takeovers in the Greek market. At a macroeconomic level, Kish and Vasconcellos (1993) estimated to what extent financial factors, such as exchange rate, stock price or interest rate, influenced M\&A between Japanese and American firms. Using a gravity equation, Di Giovanni (2005) explored macroeconomic and country level financial determinants of cross-border M\&A flows.

To sum up, rst evidences from the existing literature point out that Greenfield Investments and cross-border M\&A have no reason to be identical or completely different, as confirmed by some very recent theoretical works. Cross-border M\&A are not only a way of servicing foreign markets, but also a means of restructuring industries. ${ }^{9}$ In this context, this paper contributes to fill this gap. We investigate what kind of factors determines the pattern of cross-border M\&A locations. We examine location choices of M\&A between 18 OECD members' firms over the period 1990-1999. Location factors are depicted at two distinct levels. At a sector level, we include three different ones: market size, labor costs and productivity. This study encompasses 18 manufacturing and services sectors. At a country level, we first use some common determinants of FDI: corporate tax, geographic and cultural distances and market access. In addition to these traditional variables affecting FDI

${ }^{9}$ See on cross-border M\&A and their interactions with Greenfield Investments e.g. Bertrand (2005), Bjorvatn (2001), Gö rg (2000) or Norbä ck and Persson (2002), and on cross-border M\&A only, Horn and Persson (2001) or Neary (2004). 5 
location, we take into account some specific determinants of M\&A related to market structure and regulation. The availability of acquisition candidates is captured by the variables market capitalization and privatization activity. We also control for the influence of ownership structure, legal rules, as well as the existence of bandwagon effects, i.e. imitation behaviors.

We follow two methods of estimation: the conditional logit (McFadden, 1984) and the count model (Poisson or negative binomial model). These complementary methods enable us to shed light on robust findings. In spite of the use of distinct econometric methods, we find that the supply of target firms (captured by the market capitalization and the privatization activity) constrains the location of M\&A. This result agrees with previous studies (e.g. O'Huallachain and Reid 1997 or Basile 2004). Also, Di Giovanni 2005 found an important role of market capitalization in explaining M\&A flows. However, it is not the only determinant of location: the market size, the labor cost, the market access and the financial openness play a positive and significant role in the M\&A location process. A bandwagon effect is also observed. In the opposite, the corporate tax rate and the productivity decrease the probability to attract M\&A. Only the ownership structure has contrasted results. In addition, cultural and geographic distances as well as difference in legal rules in the conditional logit case exert a negative significant impact on M\&A strategies.

The paper proceeds as follows: first, the section 2 briefly presents the econometric model. The section 3 indicates the variables used in the set of estimations. Then, we discuss empirical findings in section 4 . The section 5 concludes this article.

\section{The Econometric Model: Location Choices}

\section{A. Location choices of Greenfield Investments and M\&A}

The decision of an investor i to locate abroad in a country $j$ depends on its investment profit denoted $\Pi_{j}$. To simplify, this investment profit is equal to the gross profit $\Pi_{j}^{g}$ minus the investment price $P$. In this context, could location determinants of cross-border M\&A be different from those of Greenfield Investments ?

In a first step, let us compare the gross profit $\Pi_{j}^{g}$ withdrawn from a cross-border M\&A operation to that from a Greenfield Investment one: these two entry modes could bring about distinct consequences in terms of turnover and production cost. The building of a new plant raises the production capacity of an industry. It 
increases competition on the host country market. Reversely, a cross-border M\&A is likely to reduce it. As a result, Greenfield Investments could reveal to be more sensible to the market size of the host country. Similarly, these two FDI modes may not entail the same production structure. A Greeneld Investment may come with a duplication of foreign firms' technology abroad. Inversely, M\&A may generate efficiency gains. They allow companies not only to exploit their existing technological and/or organizational edge on foreign markets, but also to access quickly new knowledge assets. ${ }^{10}$ These two entry modes could therefore respond differently to the technology, or more generally to the economic development level of host countries.

The investor has to subtract the investment price $P$ from its gross profit. In the Greenfield Investment case, he has to pay a plant-level fixed cost. This cost is mainly exogenous. Taking over local firm incurs an investment price too. However, this acquisition price is endogenous to large extent: the price acquisition level depends on strategic interactions among firms. Nö rback and Persson (2003) very clearly stress this theoretical distinction between these two FDI modes (p.3): “To this end, we make the following distinction between entry by acquisition and green field entry: the domestic assets are in scarce supply and the price is determined in an auction acquisition game. The limited availability of these assets may be associated with the acquired firm having privileged access to the distribution system, ownership of land or permits, knowledge of the specific characteristics of the local market, locally well-known brand names, or assets already in the market allowing early entry. The variable cost of greenfield investment (new investments), is on the other hand, assumed to be fixed. This is motivated by the fact that the supply of inputs (labor and capital) used in these investments to large extent consists of inputs used in many other industries in the economy and the investor in a particular industry could then be seen as price taker." Consequently, the acquisition price is related to industry and host country characteristics. Let us take an example: rise in production costs in a host country may reduce not only the gross profit of the investing firm, but also the acquisition price, since the profit of the domestic target firm decreases in parallel. The acquisition price also depends on the supply of target firms in the host

\footnotetext{
${ }^{10} \mathrm{By}$ setting up a plant in a foreign market, a firm is also able to access local technology and knowledge through spill-overs from domestic firms, but certainly to a lower extent. In addition, it takes more time.

${ }^{11}$ Such an argument may be extended, but to a lower extent, to Greenfield Investments (e.g. no available land for the factory set-up).
} 
market for corporate control. The scarcity of domestic firms, or the impossibility to buy them, for instance because of very concentrated ownership pattern, may constitute a major obstacle to $M \& A .{ }^{11}$ In addition, there may exist some further costs with $M \& A$ related to the merging firms' organizational integration. They could make M\&A more sensible to the cultural distance or differences in corporate governance regime between home and host countries than Greeneld Investments.

In this paper, we focus on the location choices of M\&A. By assumption, we omit any trade-off between cross-border M\&A and Greefineld Investments. This assumption relies on the nature of our database (see section 3). It records M\&A between large multinational firms. Given the size of M\&A investments, Greenfield Investments may not constitute a realistic alternative to the firms' external growth. ${ }^{12}$ In the opposite, it does not prevent export activities as an alternative entry mode to cross-border M\&A. Thus, consider a firm located in a country $i$. This firm wishes to acquire a company in one out of $\mathrm{n}$ countries indexed by $j$ with $j=1, \ldots, n$ $(i \neq j)$. Thus, it has $\mathrm{n}$ alternative choices. ${ }^{13} \mathrm{We}$ denote $\Pi_{j}$ the gain that the firm $i$ obtained from merging with an other country $j^{\prime} s$ firm. This gain depends on country or sector level characteristics $X_{s}$ in both countries, with sectors $s=1, \ldots$, $S{ }^{14}$ Therefore, merging profits are rewritten as follows: $\Pi_{j}=\Pi\left(X_{s}^{i}, X_{s}^{i}\right)$. The firm $i$ chooses the location $j$ yielding the highest gain $\Pi_{j}$. Different econometric estimations may model M\&A location choices. We will first present the conditional logit, then the count model.

\section{B. Econometric estimation of location choices}

\section{a) The conditional logit}

The conditional logit is the most frequently used method when examining location choices. It is based on the MacFadden's model of multinomial logit. With this method, regressions are implemented and clustered by M\&A operations. Thus,

\footnotetext{
${ }^{12}$ The 1990s saw a dramatic rise in the number and value of large-scale M\&A (OECD, 2001). A crossborder M\&A has on average doubled in size over the period 1990-1999. As a result, a Greenfield investment could not be a realistic alternative mode since it requires much more time than acquiring an existing firms. Speed is a major advantage of M\&A over Greenfield Investments. It is particularly true for a large size of investment.

${ }^{13}$ In the following, for the sake of simplicity, we do not take into account the temporal dimension in notations and mathematical expressions.

${ }^{14} \mathrm{We}$ assume homogeneity among firms of a given sector in an observed country.
} 
for each M\&A operation, the characteristics sector/country/year of the purchaser firm do not vary. Only bilateral and country $j$ 's characteristics $X_{s}^{j}$ matter: $\Pi_{j}$ $=\Pi\left(X_{s}^{j}\right) . \Pi_{j}$ is equal to $\beta X_{s}^{j}+e_{j}$, where $X_{s}^{j}, \beta$ and $e_{j}$ are respectively observable characteristics of location $j$, a coefficient vector of estimated parameters and a random term.

A firm decides to buy out a company located in $j$ if it provides it a higher profit than buying out a firm established somewhere else in 1 . The probability to choose the location $j$ is then as follws:

$$
\operatorname{Prob}_{j}=\operatorname{Prob}\left(\Pi_{j}>\Pi_{l}\right)=\operatorname{Prob}\left(e_{l}<e_{j}+\beta\left(X_{s}^{j}-X_{s}^{l}\right)\right), \forall l \neq j
$$

If errors terms are identically and independently distributed, then the probability of locating in a country $j$ corresponds to:

$$
\operatorname{Prob}_{j}=\frac{e^{\dot{\beta} X^{j}}}{\sum_{j=1}^{n} e^{\dot{\beta} X^{j}}}
$$

By setting $d_{j}=1$ when the firm $i$ decides to located in $j$ and $d_{j}=0$ in the opposite case, the log-likelihood is written $\operatorname{logLL}=\sum_{k=1}^{N} \sum_{j=1}^{n} d_{k j} \log \operatorname{Prob}_{k j}$, where $\mathrm{N}$ is the whole sample of investments. Besides, all variables are transformed into logs. Therefore, each coefficient is roughly expressed as an elasticity function for an average buyer (Crozet, Mayer and Mucchielli, 2004). It indicates how the probability of taking over a domestic firm is modified by a variation in an explanatory variable. From equation 2 , this elasticity is equal to:

$$
\frac{\partial \operatorname{Prob}_{j}}{\partial X_{s}^{j}} \frac{X_{s}^{j}}{\operatorname{Prob}_{j}}=\beta_{s}\left(1-\operatorname{Prob}_{j}\right)
$$

where $\beta_{s}$ is the estimated coefficient of the variable $X_{s}^{j}$. This coefficient slightly overestimates the elasticity of location choices probability. However, this overestimation can be evaluated and then corrected. ${ }^{15}$ Nevertheless, the conditional logit model is perfectly valid only if the assumption of independence of irrelevant alternatives is respected: $e_{j}$ are supposed to be independent between all choices. It

\footnotetext{
${ }^{15}$ The average probability to choose the location $\mathrm{j}$ is equal to $P r o b_{j}=\frac{1}{n}$, where $\mathrm{n}$ is the number of alternative choices. For instance, if we have 18 alternative choices, coefficients must be multiplied by 0.944 .
} 
implies that the ratio of probabilities of any two alternatives is unaffected by the choice set. After having controlled observable variables, location choices should be considered to be symmetrically substitutable. In this respect, Guimaraes et al. (2000; 2003 ) point out that using a count model is equivalent to implement a conditional logit model without relying on the assumption of independence of random terms. The count model is an estimation of a Poisson distribution. With this method, the number of M\&A for a year/ sector / target firm's country are aggregated, making us losing information on the initial location of the buyer.

\section{b) The count model}

The count model was proposed by Hausman et al. (1984). In the count model, the probability that $y_{i}$ firms of country $j$ are taken over is written:

$$
\operatorname{Prob}\left(y_{i}\right)=f\left(X_{s}^{j}\right)
$$

This discrete probability function is similar to a Poisson distribution (Greene, 1994) where $\ln \lambda_{i}=\beta X_{s}^{j}$ :

$$
\operatorname{Prob}\left(Y=y_{i}\right)=\frac{e^{-\lambda i} \lambda_{i}^{y_{i}}}{y_{i} !}
$$

However, our database may include a too large number of cells without any M\&A. Some sectors in a given country may experience no M\&A over the entire period 1990-1999. To remedy this difficulty, some authors have used the model ZIP (zero inflated Poisson model) to correct such a presence of excess zeros. ${ }^{16}$ This framework identifies a two-step decision process. First, firms choose the countries where they do not want to invest. Second, among the set of remaining countries, a Poisson process determines their respective probability of attracting foreign investments. Therefore, this method distinguishes among determinants deterring firms from investing and those explaining the number of foreign firms attracted in a given country : underlying mechanisms generating zeros and nonzero counts are distinct. In the model ZIP, $y_{i}$ take the value zero with a probability $\varphi_{i}$ and follows a Poisson distribution $\left[\lambda_{j}\right]$ with a probability $1-\varphi_{i}$ :

$$
\operatorname{Prob}\left[y_{j}=0\right]=\varphi_{j}+\left(1-\varphi_{j}\right) e^{\left(-\lambda_{j}\right)}
$$

\footnotetext{
${ }^{16}$ See Lambert (1992), Henderson (1996), Cameron and Trivedi (1998), List (2001) or Girma (2002).
} 


$$
\operatorname{Prob}\left[Y=y_{i} \mid Y>0\right]=\left(1-\varphi_{j}\right) \frac{e^{\left(-\lambda_{j}\right)} \lambda_{j}^{y_{j}}}{y_{j} !}
$$

$\varphi_{i}$ follows a logistic transformation of parameter $X^{j}$ where $X^{j}$ is the vector of variables influencing non-investment decisions. ${ }^{17}$ The Vuong's test (1989) enables us to statistically discriminate between the model ZIP and the standard model. We calculate this statistic in each regression of a Poisson model. A standard count data model is the most appropriate specification if there is no separate process for the zero count.

However, a restrictive property of the Poisson model is the mean-variance equivalence, which is also called equidispersion. The violation of this restriction leads to the same consequence as the presence of heteroscedasticity in a OLS model: the value of parameters are consistent but inefficient. Variances are biased, which invalidates hypothesis tests. In this case, we have to adopt a negative binomial model which relaxes the constraint of equidispersion by adding a gammadistributed error term into the Poisson model. The probability distribution of the negative binomial model is as follows:

$$
\operatorname{Prob}\left(Y=y_{i} \mid u\right)=\frac{e^{-\lambda_{j}^{e}\left(u_{j}\right)} \lambda_{j}^{y_{j}}}{y_{j} !}
$$

where $e^{\left(u_{j}\right)}$ has a gamma distribution with a mean and a variance equal respectively to land $\alpha$.

The negative binomial model allows an over-dispersion corresponding to:

$$
\operatorname{Var}\left[y_{i j}\right]^{\prime} E\left[y_{i j}\right]=1+\alpha_{j} E\left[y_{i j}\right]
$$

We apply a likelihood ratio test for each regression associated with a count model. If $\alpha$ differs significantly from 0 , the test asserts that an over-dispersion exists, recommending the implementation of a negative binomial model. The Vuong test remains valid to discriminate between a negative binomial model with (model ZINB - Zero inflated negative binomial) or without excess zeros (negative binomial model).

\footnotetext{
${ }^{17}$ Following Girma (2002) and Basile (2004), we use the same set of variables in the first and second step. There is no reason to think that these two processes have distinct determinants.
} 


\section{Description of Variables and their Expected Effects}

\section{A. The endogenous variable}

In the conditional logit model, the endogenous variable is qualitative. It is equal to 1 (respectively 0 ) when a firm from country $i$ (does not) takes over a firm from country $j$. In the count model, the dependant variable accounts for the number of firms purchased each year in an industry of a given country. Our study covers the period 1990 - 1999. It includes 400 cross-border M\&A over a set of 18 sectors (ISIC rev3 classification) and countries. Our database (Source: DOME) encompasses all main industrial countries. ${ }^{18}$ Graphic Figure 1, as well as tables 1 and 2, describe our sample.

Graphic Figure 1 clearly displays an increasing tendency to M\&A. The number of M\&A transactions surged from 6 in 1990 to 102 in 1999. The annual growth rate was about $33 \%$ over this decade. Also, as it can be observed in table 1 , American, German, French and English multinational firms strongly participated to the process of M\&A both as buyer or target firms. In addition, table 2 shows that financial institutions largely took part in M\&A activities. Deregulated sectors such as telecommunications or transports also witnessed M\&A. Nevertheless, traditional

Figure 1. Evolution of cross-border M\&A

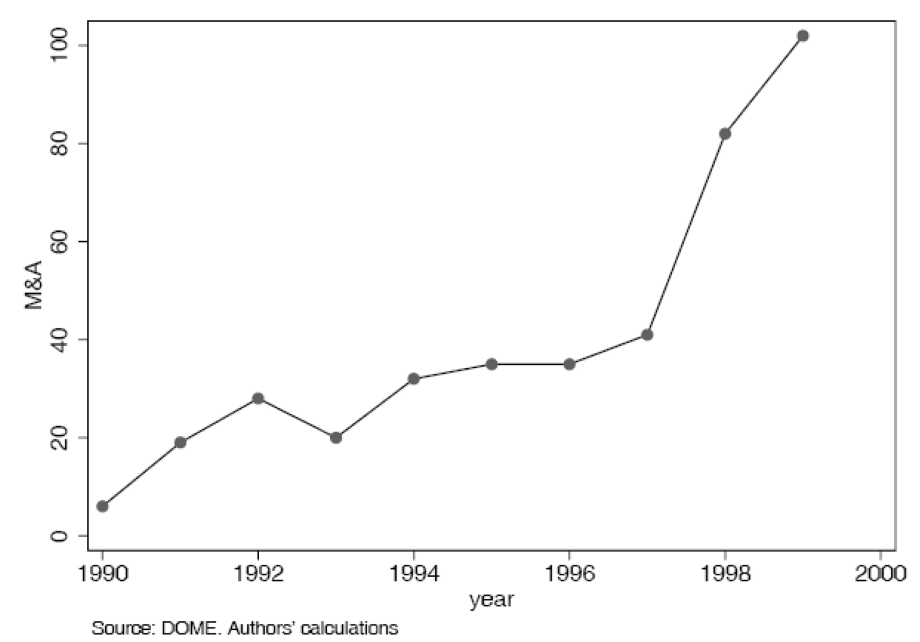

\footnotetext{
${ }^{18}$ The DOME ("Database On Mergers in Europe") database was recorded by the Institute for World Economics (University of Kiel).
} 
Table 1. Number of cross-border M\&A per country (1990-1999)

\begin{tabular}{ccc}
\hline Country & Target & Buyer firm \\
\hline Austria & 5 & 5 \\
Belgium & 19 & 11 \\
Canada & 3 & 8 \\
Denmark & 8 & 2 \\
Finland & 5 & 4 \\
France & 47 & 85 \\
Germany & 67 & 63 \\
Italy & 29 & 9 \\
Japan & 5 & 10 \\
Korea & 1 & 1 \\
Netherlands & 34 & 35 \\
Norway & 3 & 3 \\
Portugal & 5 & 0 \\
Spain & 29 & 6 \\
Sweden & 21 & 16 \\
Great-Britain & 81 & 59 \\
United-States & 37 & 78 \\
Luxembourg & 1 & 5 \\
Total & 400 & 400 \\
\hline
\end{tabular}

Source: DOME database

Table 2. Number of cross-border M\&A per sector (1990-1999)

\begin{tabular}{lcc}
\hline \multicolumn{1}{c}{ Sectors } & Buyers & Target firms \\
\hline Agriculture, hunting, forestry and fishing & 4 & 3 \\
Mining and quarrying & 4 & 6 \\
Food products, beverages and tobacco & 13 & 12 \\
Textiles, textile products, leather and footwear & 1 & 4 \\
Wood, products of wood and cork & 3 & 2 \\
Pulp, paper, paper products, printing and publishing & 10 & 9 \\
Chemical, rubber, plastics and fuel products & 54 & 52 \\
Other non-metallic mineral products & 6 & 7 \\
Basic metal and fabricated metal products & 20 & 20 \\
Machinery and equipment & 47 & 51 \\
Transport equipment & 44 & 36 \\
Manufacturing industries n.e.c and recycling & 1 & 2 \\
Electricity, gas and water supply & 12 & 8 \\
Construction & 2 & 6 \\
Wholesale and retail trade, hostels and restaurants & 37 & 43 \\
Transports, storage and telecommunication & 37 & 37 \\
Finance, insurance,real estate and business activities & 95 & 86 \\
Community, social and personal services & 10 & 16 \\
\hline
\end{tabular}


industrial sectors, like mechanical, electronics, or e.g. transport equipment industry, remained strongly affected by restructuring. Only M\&A notified by the European Commission are concerned. ${ }^{19}$ Therefore, our sample consists of M\&A between multinational companies selling goods at a very large scale on the European market. ${ }^{20}$ Joint-ventures (i.e. alliances) are excluded. Only horizontal and vertical M\&A are kept. Horizontal operations account for more than $80 \%$ of M\&A in our database. It means that we mainly investigate the location choices of horizontal M\&A.

\section{B. Independent variables}

Our econometric estimation takes into account some variables affecting traditionally FDI location and others more specific to M\&A location. We include independent variables at sector and country level. The table 3 describes data and their sources.

\section{a) Sector level variables}

Market size : we estimate the influence of Market size. A huge market size means a great local demand and easier outlets. Hence, it is expected to stimulate M\&A activities. Market size could be measured by current consumption. However, data lack on trade flows in services sectors. To keep information on them, we use the production at the sector level as a proxy of the market size.

Labor costs : this variable represents Labor costs in the host country. It provides an indication of companies' production costs in a given sector. All things being equal, a rise in the production cost should deter a company from taking over a local firm. Also, this variable could approximate the structure of employment: a higher share of qualified employees results in higher wages per capita, which could reverse the former effect.

Productivity : the variable productivity gives information on the productivity level in a given sector of a country. It indicates the technological level of host

\footnotetext{
${ }^{19} 11$ M\&A notified over the period 1990-1999 were prohibited. Companies are usually able to address competition issues by divesting a part of their business. We have kept these data, since they reflect real location choices.

${ }^{20} \mathrm{~A} \mathrm{M} \& \mathrm{~A}$ has a community dimension if the combined aggregate worldwide turnover of all the companies concerned is more than 5000 million Euros and the community-wide turnover of each of at least two of the companies is more than 250 million Euros, unless these companies achieve more than two-thirds of their community-wide turnover within one and the same member state.
} 
country firms. On the one hand, a higher productivity could foster the take-over of domestic firms if buyers are willing to absorb tangible and intangible assets hold by high-technology firms. On the other hand, productivity could approximate the profitability of target firms, which affects the acquisition price. A firm endowed with a low productivity should be taken over at a lower acquisition price. In addition, a M\&A transfers the ownership of existing productive assets from a less efficient firm to a more efficient one. The buyer brings its superior technology to the target firm engendering efficiency gains. ${ }^{21}$ As a result, the sign associated with this variable is not obvious. Note that $R \& D$ indicators have not be retained for two reasons. First, productivity is a larger measure reflecting not only technology, but also management efficiency. Second, there is unfortunately no information on R\& D expenditures in many services sectors.

Follower : the variable Follower represents the total number of M\&A per sector-country over the three year period preceding each M\&A. This variable captures imitative and strategic behaviors among multinational firms. By investing abroad, firms may be willing to prevent any competitive advantage to the leader in the host country (Knickerbocker, 1973). In addition, rival firms' incentives to merge may increase when two competing firms merge (Caves, 1991; Fauli-Oller, 2000). Managers may also imitate each other to minimize their business risk. ${ }^{22}$ According to Schenk (1996), it is better to make the same mistake as the colleagues, than to be the only one to take the right decision with the risk of being the only one to make a mistake. As a result, the sign of the variable Follower is expected to be positive. However, an investment opportunity effect through the reduction in number of available target firms could soften this bandwagon effect. ${ }^{23}$

\footnotetext{
${ }^{21}$ Because of factor markets failure, transfers of valuable intangible assets (e.g. know-how) incur too expensive transaction costs (Caves, 1996).

${ }^{22}$ In addition to imitation phenomena, managerial behaviors (power building etc.) or non-anticipated postmerger difficulties (wrong evaluation of synergy gains, underestimation of culture clashes etc.) may also explain the high rate of M\&A failure.

${ }^{23}$ This variable may also capture agglomeration effects. According to new theories of economic geography (see Fujita et al., 1999), a greater number of firms in a given host country exercises two opposite forces: a competition eect and positive externalities. On the one hand, it increases competition among firms, which deters them from locating in the host country. On the other hand, it causes positive externalities by improving input market access, strengthening technological spillovers or reinforcing vertical input-output links with other firms.
} 


\section{b) Country level variables}

Geographic distance : this variable estimates the geographic distance between two countries. On the one hand, a high distance encourages companies to invest abroad rather than export towards the host country. On the other hand, it increases the costs of coordination and information on foreign markets, which dissuades them from investing overseas. The net effect of geographic distance is then ambiguous.

Cultural distance : this variable accounts for the cultural distance between two countries (Morosini et al., 1998). Four dimensions are identified (Hofstede, 1983): ${ }^{24}$ power distance, uncertainty avoidance, individualism-collectivism and masculinityfemininity. ${ }^{25}$ A high cultural distance tends to increase the operational costs of foreign subsidiaries and to raise the risk associated with FDI. In addition, it makes organizational and technological skills less easily transferable. A high cultural distance may also increase the organizational cost of firms' integration because of less cooperation between teams etc. These costs harm the profitability of crossborder M\&A.

Corporate tax : this variable indicates the average tax imposed on the income of corporation. All else being equal, a rise in corporate taxes reduces expected merging gains. Therefore, it should have a deterrent effect on M\&A.

Market access : the variable market access assesses trade integration between two countries. We approximate bilateral access to markets $i$ and $j$ by the value $\phi_{i, j}, \phi_{i j}$ is called the "phi-ness" of the trade: ${ }^{26}$

$$
\phi_{i j}=\sqrt{\frac{m_{i j} m_{j i}}{m_{i i} m_{j j}}}
$$

where $m_{i j}$ (respectively $m_{j i}$ ) represents the imports of $i(j)$ coming from $j(i)$ and $m_{i i}\left(m_{j j}\right)$ are local sales (production minus exports) in country $i(j)$. This variable $\phi_{i j}$ lies between 0 and 1 . The closer it is to 1 , the more markets are integrated. Two

\footnotetext{
${ }^{24}$ Surveys were collected in 66 countries in the 1970 's. However, they are still valid since culture remains relatively stable over several generations.

${ }^{25}$ Power distance reflects the degree to which a culture believes how institutional power should be distributed (equally or unequally) and how the decisions should be viewed (accepted or not). Uncertainty avoidance refers to the extent to which a culture feels threatened by uncertain and risky situations. Individualism-Collectivism describes the degree to which a culture has allegiance to the group. MasculinityFemininity indicates the degree to which a culture values behaviors such as acquisition of wealth or e.g. caring for others. ${ }^{26}$ Its calculation is derived from the model of Dixit-Stiglitz-Krugman monopolistic competition (see Head
and Mayer, 2004).
} 
opposite effects are expected. If FDI are motivated by the "tariff jumping" argument, a better market access should have a negative effect on the incentives to merge: firms have fewer gains to locate abroad in order to remove exporting trade costs. However, an increasing market access means also tougher competition. It could push companies to consolidate to restore their mark-up and to take advantage of lower acquisition prices. In addition, Horn and Persson (2001) stress that high trade costs may be conductive to domestic M\&A rather than cross-border M\&A, and inversely.

Market capitalization and Privatization : the market capitalization of listed companies gives information on M\&A opportunities in a given country. The supply of procurable target firms may constraint the location choice of M\&A. With a fall in market capitalization, the available pool of domestic companies shrinks, which constitutes a friction factor refraining $M \& A$ due to mismatching between supply and demand, etc. This variable also provides a measure of financial deepening, i.e. of the size of financial markets. Deepening financial markets help firms to overcome their internal financing constraints because firms are able to access larger and cheaper funds. It is expected to reinforce industrial restructuring. The variable privatization indicates the intensity of privatization activity. As a rise in market capitalization, the sale of owned-state assets should make the entry of foreign firms easier by relaxing the scarcity constraint on available domestic firms.

Ownership structure : this indicator evaluates the shareholders' dispersion within firms. It corresponds to the share of companies where there are no controlling shareholders. ${ }^{27}$ Large investors in the company board of directors are able to monitor the incumbent management and to replace it when it performs poorly. With disperse ownership structure, M\&A play a more important role as a disciplining mechanism for controlling managers' behaviors (Healy and Palepu, 1994; Hart, 1995). In addition, a concentrated ownership pattern is more likely to constitute an entry barrier to new investors, when owners have decided to protect the incumbent management. Small and numerous owners are a priori less reluctant to trade their shares. ${ }^{28}$ Therefore, a growing share of domestic firms widely held

\footnotetext{
${ }^{27} \mathrm{~A}$ shareholder is defined to control a company if its voting rights (hold directly or indirectly) are at least higher than $20 \%$.

${ }^{28}$ Financial literature on corporate governance has examined links between ownership structures and takeovers. To this respect, Grossman and Hart (1980) stressed free-riding behaviors for widely-held corporations: target shareholders anticipating that the post-takeover value of the firm will be higher than the tender price may prefer to hold their shares and wait that other shareholders sell theirs. As a result, no takeover may occur.
} 
should make M\&A easier to implement.

Legal rules : the variable Legal rules identifies the legal origin of the commercial law: common law (English origin) versus civil law (Romano-Germanic legal tradition). It is equal to 1 when the target and the buyer countries belong to the same system of legal rules. The empirical study led by Lopez-de-Silanes et al. (1998) points out that common law countries offer stronger legal protection for investors than civil law countries. In our case, the variable Legal rules reflects some differences in corporate governance regime within a country, since the legal framework of a country certainly shapes the corporate governance at a firm level (Bris and Cabolis, 2002). ${ }^{29}$

Table 3. Variables and data sources

\begin{tabular}{|c|c|}
\hline market size & $\begin{array}{l}\text { production (current prices*) } \\
\text { (STAN database - OECD ISIC Rev 3, } 1990 \text { - 1999) }\end{array}$ \\
\hline \multirow[t]{2}{*}{ labor costs } & $\begin{array}{l}\text { average wage per worker (current prices) } \\
\text { (STAN database - OECD ISIC Rev 3, } 1990 \text { - 1999) }\end{array}$ \\
\hline & average productivity per worker (current prices) \\
\hline \multirow[t]{2}{*}{ productivity } & $=\frac{\text { value added }}{\text { employment }}$ \\
\hline & (STAN database - OECD ISIC Rev 3, 1990 - 1999) \\
\hline \multirow[t]{2}{*}{ geographic distance } & $\begin{array}{l}\text { geographic distance between capitals of two countries } \\
\text { (CEPII database on geodesic distances) }\end{array}$ \\
\hline & cultural distance between countries A and B \\
\hline \multirow[t]{2}{*}{ cultural distance } & $\sqrt{\sum_{i=1}^{i=4}\left(I_{i A}-I_{i B}\right)^{2}}$ with $I$ the score for the $i$ Hofstede's cultural dimension \\
\hline & (Authors' calculations from Hofstede (1983)) \\
\hline corporate tax & average corporate tax per country (Word Tax Database, OTPR) \\
\hline market access & $\begin{array}{l}\text { measure of bilateral market access (Authors' calculations from STAN } \\
\text { database - OECD ISIC Rev 3, } 1990 \text { - 1999) }\end{array}$ \\
\hline capitalization & $\begin{array}{l}\text { market capitalization of listed companies at current prices } \\
\text { (World Development Indicators, Word Bank) }\end{array}$ \\
\hline privatization & $\begin{array}{l}\text { Amount raised by privatization value per country } \\
\text { (Mahboobi, 2002, OECD) }\end{array}$ \\
\hline ownership structure & share of firms without controlling shareholder (La Porta et al., 1999) \\
\hline legal rules & $\begin{array}{l}\text { similarity (or not) of legal rules in home and host countries } \\
\text { (La Porta et al., 1998) }\end{array}$ \\
\hline financial openness & share of stocks hold by foreign residents on the stock market (Eurostat) \\
\hline follower & $\begin{array}{l}\text { total number of M\&A per sector-country over the three year period } \\
\text { preceding each M\&A (DOME) }\end{array}$ \\
\hline
\end{tabular}

*All variables expressed in value are converted in U.S. dollars. 
Financial openness : this variable is a proxy of the openness in financial markets. It represents the share of stocks hold by foreign residents on the host country stock market. ${ }^{30}$ A positive effect is expected: a rise in financial openness indicates least effective impediments on foreign investors. Furthermore, it is a priori associated with a better and more transparent information on investment opportunities and a greater confidence of foreign investors in the economy of the host country.

Finally, we introduce years fixed effects in regressions. They control the temporal dimension of $M \& A$, capturing effects common to all countries and industries. ${ }^{31}$ Indeed, our estimations are likely to be biased by a temporal effect, since mergers are observed to come in waves empirically (Andrade et al., 2001). Our window of analysis coincides with the fifth M\&A wave (graphic 1).

\section{Empirical results and interpretations}

In our estimations, we proceed as follows. First, we make out our regressions using the conditional logit method. Then, we employ the count model.

\section{A. Location of cross-border Mergers and Acquisitions: the conditional logit estimation}

Tables 4, 5 and 6 display respectively econometric outcomes for the conditional logit and the count model. The last column of each table reports the results for manufacturing sectors only.

The conditional logit specification gives the following conclusions: the traditional FDI variable market size has the expected sign. As in numerous studies on FDI location, it is found to be positive and significant in all our different estimations. ${ }^{32}$ The labor cost has a significant (except in columns 4 and 5), but positif impact. This variable records a non-intuitive sign as in some analysis on FDI location: ${ }^{33}$ all

\footnotetext{
${ }^{29}$ Corporate governance refers to the way in which shareholders exert control over the corporation.

${ }^{30}$ Unfortunately, this variable is available only for 10 countries (Austria, Belgium, Finland, France, Germany, Italy, Netherland, Norway, Spain and Sweden). It will be included only into few regressions.

${ }^{31}$ We have not included year dummies in the conditional logit estimation. There is no variability among alternative choices since regressions are implemented by year.

${ }^{32}$ In columns 4 and 5 , the elasticity associated with market size is slightly more important: it might be due to the size of our sample that is dramatically reduced with the inclusion of the variable financial openness.
} 
Table 4. Cross-border M\&A: Conditional logit

\begin{tabular}{|c|c|c|c|c|c|c|c|}
\hline & (1) & (2) & (3) & (4) & (5) & (6) & (7) \\
\hline \multirow[t]{2}{*}{ market size } & $0.334^{\mathrm{a}}$ & $0.275^{\mathrm{a}}$ & $0.228^{\mathrm{b}}$ & $0.686^{\mathrm{a}}$ & $0.875^{\mathrm{a}}$ & $0.177^{b}$ & $0.304^{\mathrm{c}}$ \\
\hline & $(0.070)$ & $(0.082)$ & $(0.091)$ & $(0.177)$ & $(0.219)$ & $(0.077)$ & $(0.106)$ \\
\hline \multirow[t]{2}{*}{ labor cost } & $0.779^{b}$ & $0.782^{b}$ & $0.855^{\mathrm{b}}$ & 0.567 & 0.739 & $0.647^{\mathrm{c}}$ & $1.640^{\mathrm{c}}$ \\
\hline & $(0.349)$ & $(0.349)$ & $(0.373)$ & $(0.444)$ & $(0.500)$ & $(0.348)$ & $(0.540)$ \\
\hline \multirow[t]{2}{*}{ productivity } & $-0.632^{b}$ & -0.499 & -0.449 & $-1.014^{b}$ & $-1.232^{b}$ & -0.487 & $-0.832^{\mathrm{a}}$ \\
\hline & $(0.315)$ & $(0.323)$ & $(0.350)$ & $(0.431)$ & $(0.496)$ & $(0.324)$ & $(0.453)$ \\
\hline \multirow[t]{2}{*}{ capitalization } & $0.305^{\mathrm{a}}$ & $0.303^{\mathrm{a}}$ & $0.245^{\mathrm{a}}$ & -0.120 & $-0.337^{\mathrm{a}}$ & $0.232^{\mathrm{a}}$ & $0.314^{\mathrm{c}}$ \\
\hline & $(0.045)$ & $(0.046)$ & $(0.051)$ & $(0.103)$ & $(0.130)$ & $(0.047)$ & $(0.060)$ \\
\hline \multirow[t]{2}{*}{ corporate tax } & $-0.942^{c}$ & -0.772 & -0.539 & 0.288 & $1.553^{\mathrm{b}}$ & $-0.987^{c}$ & -0.648 \\
\hline & $(0.485)$ & $(0.527)$ & $(0.629)$ & $(0.597)$ & $(0.774)$ & $(0.532)$ & $(0.726)$ \\
\hline \multirow[t]{2}{*}{ privatization } & $0.044^{\mathrm{a}}$ & $0.040^{\mathrm{a}}$ & $0.033^{\mathrm{a}}$ & $0.042^{c}$ & $0.138^{\mathrm{b}}$ & $0.050^{\mathrm{a}}$ & $0.039^{c}$ \\
\hline & $(0.010)$ & $(0.010)$ & $(0.011)$ & $(0.024)$ & $(0.059)$ & $(0.010)$ & $(0.014)$ \\
\hline \multirow[t]{2}{*}{ distance } & $-0.438^{a}$ & $-0.454^{\mathrm{a}}$ & $-0.402^{\mathrm{a}}$ & & & & $-0.340^{c}$ \\
\hline & $(0.053)$ & $(0.055)$ & $(0.064)$ & & & & $(0.079)$ \\
\hline \multirow[t]{2}{*}{ ownership structure } & & 0.070 & 0.080 & $0.489^{\mathrm{a}}$ & $0.725^{\mathrm{a}}$ & 0.157 & 0.083 \\
\hline & & $(0.095)$ & $(0.106)$ & $(0.134)$ & $(0.161)$ & $(0.098)$ & $(0.133)$ \\
\hline \multirow[t]{2}{*}{ follower } & & $0.149^{\mathrm{a}}$ & & & -0.030 & & \\
\hline & & $(0.048)$ & & & $(0.067)$ & & \\
\hline \multirow[t]{2}{*}{ cultural distance } & & & & $-0.232^{\mathrm{a}}$ & $-0.278 \mathrm{a}$ & $-0.147^{b}$ & \\
\hline & & & & $(0.086)$ & $(0.094)$ & $(0.071)$ & \\
\hline \multirow[t]{2}{*}{ market access } & & & & $0.679^{\mathrm{a}}$ & $0.794^{\mathrm{a}}$ & $0.551^{\mathrm{a}}$ & \\
\hline & & & & $(0.121)$ & $(0.139)$ & $(0.061)$ & \\
\hline \multirow[t]{2}{*}{ financial openness } & & & & $0.532^{b}$ & $0.817^{\mathrm{b}}$ & & \\
\hline & & & & $(0.263)$ & $(0.329)$ & & \\
\hline \multirow[t]{2}{*}{ legal rules } & & & & & & $0.338^{\mathrm{b}}$ & \\
\hline & & & & & & $(0.157)$ & \\
\hline Observations & 6800 & 6389 & 5540 & 2993 & 2616 & 6101 & 3267 \\
\hline Log likelihood & -928.549 & -918.752 & -796.535 & -514.081 & -438.492 & -883.627 & -455.909 \\
\hline Pseudo $\mathrm{R}^{2}$ & 0.18 & 0.17 & 0.17 & 0.20 & 0.23 & 0.18 & 0.19 \\
\hline LR chi $^{2}$ & 409.47 & 375.63 & 326.05 & 263.36 & 254.84 & 384.38 & 219.76 \\
\hline Prob $>\mathrm{chi}^{2}$ & 0.000 & 0.000 & 0.000 & 0.000 & 0.000 & 0.000 & 0.0000 \\
\hline
\end{tabular}

Standard errors in parentheses

${ }^{\mathrm{c}}$ significant at $10 \%$; ${ }^{\mathrm{b}}$ significant at $5 \%$; ${ }^{\text {a }}$ significant at $1 \%$ All variables are in logarithm

things being equal, a rise in labor costs should have a deterrent effect on foreign investors. The positive effect of this variable may come from a correlation with

\footnotetext{
${ }^{33}$ Head and Ries (1996), Ferrer (1998) or e.g. Devreux and Griffith (1998) find a non-significant effect. Smith and Florida (1994) point out in the automobile sector that the increase in labor costs has a positive influence on Japanese FDI in American counties.
} 
Table 5. Cross-border M\&A: Count model (first stage)

\begin{tabular}{|c|c|c|c|c|c|}
\hline & ZINB(1) & $\mathrm{ZINB}(2)$ & $\mathrm{ZINB}(3)$ & $\mathrm{ZIP}(4)$ & $\mathrm{ZINB}(5)$ \\
\hline \multirow[t]{2}{*}{ market size } & $-0.832^{\mathrm{c}}$ & $-0.876^{\mathrm{c}}$ & -0.446 & $-2.184^{\mathrm{c}}$ & $-1.789^{b}$ \\
\hline & $(0.317)$ & $(0.294)$ & $(0.312)$ & $(0.520)$ & $(0.698)$ \\
\hline \multirow[t]{2}{*}{ labor cost } & $-3.934^{\mathrm{c}}$ & $-3.885^{\mathrm{c}}$ & $-5.438^{c}$ & $-3.841^{b}$ & $-6.753^{b}$ \\
\hline & $(1.281)$ & $(1.170)$ & $(1.830)$ & (1.519) & $(3.056)$ \\
\hline \multirow[t]{2}{*}{ productivity } & $2.838^{\mathrm{c}}$ & $3.031^{\mathrm{c}}$ & $3.638^{\mathrm{c}}$ & $5.866^{\mathrm{c}}$ & 0.582 \\
\hline & $(0.873)$ & $(0.843)$ & (1.202) & (1.814) & (1.753) \\
\hline \multirow[t]{2}{*}{ capitalization } & $-1.225^{\mathrm{c}}$ & $-0.802^{c}$ & $-0.856 b$ & 0.745 & $-2.372^{c}$ \\
\hline & $(0.248)$ & $(0.275)$ & $(0.341)$ & $(0.468)$ & $(0.629)$ \\
\hline \multirow[t]{2}{*}{ corporate tax } & $11.139^{c}$ & $9.791 \mathrm{c}$ & $14.796^{\mathrm{c}}$ & 2.117 & $22.803^{c}$ \\
\hline & $(3.598)$ & $(3.147)$ & $(5.344)$ & $(2.622)$ & $(7.598)$ \\
\hline \multirow[t]{2}{*}{ privatization } & -0.058 & -0.055 & $-0.318^{b}$ & 0.113 & -0.122 \\
\hline & $(0.056)$ & $(0.055)$ & $(0.136)$ & $(0.105)$ & $(0.123)$ \\
\hline \multirow[t]{2}{*}{ market access } & & -0.831 & $-1.068^{b}$ & & \\
\hline & & $(0.521)$ & $(0.513)$ & & \\
\hline \multirow[t]{2}{*}{ ownership structure } & $5.557^{\mathrm{c}}$ & $3.903^{c}$ & $2.703^{c}$ & 0.501 & $13.494^{\mathrm{c}}$ \\
\hline & $(1.660)$ & $(1.146)$ & $(1.002)$ & $(0.805)$ & (4.119) \\
\hline \multirow[t]{2}{*}{ follower } & & & $-1.267^{b}$ & & \\
\hline & & & $(0.610)$ & & \\
\hline \multirow[t]{2}{*}{ nancial openness } & & & & $-3.479^{b}$ & \\
\hline & & & & (1.392) & \\
\hline \multirow[t]{2}{*}{ Constant } & $76.330^{\mathrm{c}}$ & $58.620^{\mathrm{c}}$ & $61.091^{\mathrm{c}}$ & 19.974 & $199.290^{c}$ \\
\hline & $(20.990)$ & $(17.766)$ & $(20.951)$ & $(15.681)$ & $(55.658)$ \\
\hline Observations & 3060 & 2970 & 2106 & 2160 & 2040 \\
\hline Likelihood ratio test $(\alpha=0)$ & 39.69 & 20.61 & 9.12 & 0.00 & 5.76 \\
\hline Prob $\geq$ chibar2 & 0.0000 & 0.0000 & 0.0000 & 1.0000 & 0.0082 \\
\hline Vuong's statistics & 3.65 & 3.72 & 4.20 & 4.29 & 3.91 \\
\hline
\end{tabular}

Standard errors in parentheses

csignificant at $10 \%$; ${ }^{b}$ significant at $5 \%$; ${ }^{\text {a }}$ significant at $1 \%$

All variables are in logarithm

qualifications structure at a sector level. ${ }^{34}$ Interestingly, the distinction between manufacturing and non-manufacturing sectors seems to matter. ${ }^{35}$ Manufacturing sectors respond more to labor costs: coefficient values are higher in column 7 of

\footnotetext{
${ }^{34}$ The removal of the variable productivity (or labor cost) or the introduction of the variable unit labor cost (i.e. labor cost/productivity) does not change the sign and the signicativity of parameters. We also lagged these variables to remove potential endogeneity problems. However, we did not get significant variations in parameters.

${ }^{35}$ In the opposite, the coefficient of other parameters remain very stable.
} 
Table 6. Cross-border M\&A: Count model (second stage)

\begin{tabular}{|c|c|c|c|c|c|}
\hline & ZINB(1) & $\mathrm{ZINB}(2)$ & ZINB(3) & $\mathrm{ZIP}(4)$ & $\mathrm{ZINB}(5)$ \\
\hline \multirow[t]{2}{*}{ market size } & $0.574^{\mathrm{c}}$ & $0.527^{\mathrm{c}}$ & $0.415^{\mathrm{c}}$ & $0.450^{\mathrm{c}}$ & $0.565^{\mathrm{c}}$ \\
\hline & $(0.069)$ & $(0.078)$ & $(0.070)$ & $(0.119)$ & $(0.095)$ \\
\hline \multirow[t]{2}{*}{ labor costs } & 0.301 & -0.016 & -0.073 & 0.119 & $1.985^{\mathrm{c}}$ \\
\hline & $(0.268)$ & $(0.282)$ & $(0.272)$ & $(0.330)$ & $(0.402)$ \\
\hline \multirow[t]{2}{*}{ productivity } & $0.397^{\mathrm{c}}$ & $0.594^{\mathrm{b}}$ & $0.528^{\mathrm{b}}$ & $1.119^{c}$ & $-0.904^{c}$ \\
\hline & $(0.235)$ & $(0.233)$ & $(0.206)$ & $(0.244)$ & $(0.308)$ \\
\hline \multirow[t]{2}{*}{ capitalization } & -0.079 & -0.110 & $-0.116^{c}$ & 0.120 & -0.082 \\
\hline & $(0.066)$ & $(0.069)$ & $(0.070)$ & $(0.086)$ & $(0.077)$ \\
\hline \multirow[t]{2}{*}{ corporate tax } & 0.430 & 0.308 & 0.770 & 0.763 & 0.388 \\
\hline & $(0.688)$ & $(0.700)$ & $(0.733)$ & $(0.654)$ & $(0.827)$ \\
\hline \multirow[t]{2}{*}{ privatization } & $0.060^{\mathrm{c}}$ & $0.050^{\mathrm{c}}$ & 0.015 & $0.048^{\mathrm{b}}$ & $0.055^{\mathrm{c}}$ \\
\hline & $(0.013)$ & $(0.013)$ & $(0.014)$ & $(0.025)$ & $(0.015)$ \\
\hline \multirow[t]{2}{*}{ market access } & & $0.538^{c}$ & $0.384^{\mathrm{c}}$ & & \\
\hline & & $(0.107)$ & $(0.109)$ & & \\
\hline \multirow[t]{2}{*}{ ownership structure } & $0.384^{\mathrm{c}}$ & $0.487^{\mathrm{c}}$ & $0.387^{\mathrm{c}}$ & $0.262^{\mathrm{c}}$ & $0.407^{\mathrm{b}}$ \\
\hline & $(0.139)$ & $(0.141)$ & $(0.138)$ & $(0.138)$ & $(0.168)$ \\
\hline \multirow[t]{2}{*}{ follower } & & & $0.262^{\mathrm{c}}$ & & \\
\hline & & & $(0.046)$ & & \\
\hline \multirow[t]{2}{*}{ financial openness } & & & & 0.231 & \\
\hline & & & & $(0.230)$ & \\
\hline \multirow[t]{2}{*}{ Constant } & $-19.905 c$ & $-14.767^{\mathrm{c}}$ & $-10.284^{\mathrm{c}}$ & $-28.527^{\mathrm{c}}$ & $-22.892^{c}$ \\
\hline & (3.219) & $(3.504)$ & $(3.359)$ & $(4.091)$ & (3.889) \\
\hline Observations & 3060 & 2970 & 2106 & 2160 & 2040 \\
\hline Log likelihood & -989.889 & -964.002 & -765.238 & -651.649 & -511.269 \\
\hline LR chi2 & 143.92 & 157.00 & 138.96 & 133.31 & 118.38 \\
\hline Prob $>$ chi 2 & 0.000 & 0.000 & 0.013 & 0.000 & 0.0000 \\
\hline
\end{tabular}

Standard errors in parentheses

${ }^{\mathrm{c}}$ significant at $10 \%$; ${ }^{\mathrm{b}}$ significant at $5 \%$; ${ }^{\text {a }}$ significant at $1 \%$ All variables are in logarithm

table 4. Moreover, productivity very often exerts a negative (and sometimes not) significant impact on firms' location choices. As discussed previously, this negative effect may reffect either the link between profitability of target firms and the acquisition price or technological transfers from the buyer to the target firm. More generally, the non-expected sign for the variables productivity and labor cost may stem from the specic characteristics of M\&A compared to Greenfield Investments. Thus, our results support one conclusion from the Neary's model (2004) according to which foreign companies tend to buy low-cost domestic firms. 
At a country level, the geographic distance and market access have opposite but consistent effects. ${ }^{36}$ The sign is positive for market access and negative for the geographic distance. The proximity among firms strengthens competition, which incites firms to merge. In the opposite, the cultural distance increases organizational costs, discouraging them from merging.

Thus, it is first confirmed that the geographic distribution of M\&A depends on traditional FDI variables. The supply of acquisition candidates is not the sole location determinant of M\&A. However, a rise in the supply of available target firms fitting its general specification and having desirable attributes effectively increases M\&A activity: the variable market capitalization displays a positive and significant sign. It may also suggest that the development of financial markets has a positive effect on M\&A. ${ }^{37}$ In addition, the variable privatization is positive and significant too. It emphasizes as well the idea that the supply of target firms restricts the location choices of M\&A. Nevertheless, the elasticity of this variable is very weak. This is not surprising since in most developed countries, privatization mainly took place in the 1980's.

Moreover, the ownership structure which is a more specific determinant of M\&A location does not seem to matter, except in column 4 and 5. It may result from opposite forces offsetting each other at an aggregated level (see section 3.2.2). With a more disaggregated measure (i.e. a sector rather than a country level), this variable would certainly play a more important role. The variable follower exhibits a positive and significant impact on cross-border M\&A operations. Lastly, the similarity of legal rules between buyer and target firms promotes cross-border operations.

To test the robustness of our finding, we now apply an other econometric estimation method: the count model (CM).

\section{B. Location of cross-border Mergers and Acquisitions: the count model estimation}

In a count model $(\mathrm{CM})$, each regression is associated with two different tables. Table 5 models the process of zero M\&A in a given sector/country. Coefficients express changes in the probability to attract no M\&A. In table 6 , coefficients indicate

\footnotetext{
${ }^{36}$ We have not included simultaneously these two variables because of a high degree of correlation (about 0.8 ). Such a correlation was foreseeable since the geographic distance has usually negative consequences on trade flows.

${ }^{37}$ The negative sign observable in specification 4 and 5 is certainly due to the introduction of the variable financial openness. Market capitalization then becomes correlated with market size, which obliges us to interpret with some caution coefficients for these two columns. Note that there is almost no correlation between the variables financial openness and market capitalization (about 0.1 ).
} 
the effects of variables on the number of inward M\&A in FDI recipient countries.

The Vuong statistic detects the presence of excess zeros both for the Poisson and the negative binomial model. Furthermore, the likelihood ratio test leads us to apply a ZINB model in all specifications, except for the fourth one. Note that bilateral variables such as geographical and cultural distance are to be excluded since data are now aggregated by sector/year/country. ${ }^{38}$

Analyze econometric outcomes. The effect of the market size seems to be quite robust and similar at the two different stages of the estimation: at the first stage, the coefficient is negative, which means that a larger market size decreases the probability not to attract M\&A. At the second step, the positive sign points out that an increasing demand has a positive influence on the number of firms purchased among host countries. Certainly for similar reasons, labor costs have again a counterintuitive impact in concordance with the conditional logit estimation. However, this effect occurs only at the first stage. ${ }^{39}$ At the second step, variables are not significant. Once countries have not been rejected as potential hosting countries, differences in labor costs among high labour cost sectors / countries do not play anymore. Reversely, the impact of productivity is not obvious. A rise in productivity increases the probability not to attract FDI: a company tries to buy out a firm established in a low-pro-ductivity sector/country. Then, among the group of selected low-productivity sectors/countries, productivity exerts a positive force on M\&A.

We again find a complex relation between M\&A and ownership structure. The sign of this variable is positive both at the first and second stage. ${ }^{40}$ A decrease in market capitalization (resp. privatization activity) restricts M\&A location but only in the first (second) step. The corporate tax shows the opposite (dissuading) effect, but with a larger amplitude: lower tax countries are more attractive as a group. However, conditional on being in the low tax group, variations in the corporate tax is not meaningful. ${ }^{41}$ The market access have the same (positive) effect as in the conditional logit. The variable Follower has a negative (respectively positive) sign

\footnotetext{
${ }^{38}$ The variable market access is not anymore bilateral. For each country, we calculate a non-pondered arithmetic mean of access markets with respect to each country partner.

${ }^{39} \mathrm{An}$ increase in labor costs decreases the probability to attract no M\&A.

${ }^{40}$ The rst eect could compensate for the second one, explaining the non-signicant sign of this variable in the conditional logit.

${ }^{41}$ It may also be explained by our imperfect measure of tax. Actual tax may depend on other features of the tax code such as investment allowances or for instance depreciation schedules.
} 
at the first (second) step confirming a bandwagon effect. The openness of financial markets displays a significant effect only at the first stage.

Lastly, restricting the analysis to manufacturing sectors magnifies the coefficients of almost all explaining variables in the first stage. However, in the second stage, except for labor costs and productivity, we observe quite similar qualitative and quantitative effects. For these variables, as in the logit model, the positive impact of labor costs on M\&A location is accentuated. We get a negative and positive sign respectively in the first and second step. As for the productivity, outcomes for both steps now suggest a negative effect, meaning that firms are attracted by lowefficiency local companies.

To conclude, the conditional logit and the count model give almost similar and expected estimations.

\section{Conclusion}

This paper seeks to analyze the determinants of cross-border M\&A location choices. Our study includes M\&A between OECD members' firms over the period 1990-1999. We implement two distinct econometric methods: the conditional logit and the count model. In addition to traditional variables aecting FDI location, we take into account some specific determinants of cross-border M\&A.

Although the supply of target firms (captured by the market capitalization and the privatization activity) effectively constrains the location of $M \& A$, it is found that the geographic distribution of M\&A is not determined only by the availability of domestic assets. The market size and the labor cost matter as well. They have a positive and significant effect on the M\&A location. There also seems to be a bandwagon effect. In the opposite, the corporate tax rate and productivity decrease the probability to attract M\&A. The significant negative effect of productivity suggests that cross-border M\&A are in part driven by efficiency motivations that says here technological transfers from foreign buyers to acquired domestic firms. This welfare enhancing aspect of international M\&A could attenuate usual fears raised by anti-competitive effects and the loss of national sovereignty they may imply. Furthermore, we found that economic integration -cultural and geographic proximity, similitudes in legal rules, market access and financial openness -have a stimulating effect on M\&A activity. 


\section{Aknowledgements}

We are very grateful to H. Boulho, G. Capelle-Blancard, M. Crozet, S. Girma, X. Hass, C. Mathieu, T. Mayer, D. Mirza, P. Norbäck, P. Ollivaud, N. Schmitt and D. Swenson for providing data and useful comments. We also want to acknowledge the participants at the workshop on "Effects of Foreign Acquisitions of Domestic Firms" held in Hamburg (Germany, 2003), the 51th Journées de l'Association Française de Sciences Economiques in Paris (France, 2003), the 5th European Trade Study Group conference in Madrid (Spain, 2003), the Royal Economic Society conference in Swansea (England, 2004), the conference on International M\&A in Paris (France, 2004), the CEPR school in applied industrial organization in Hydra (Greece, 2004) and the spring school of international and industrial economics organized by the GREQAM in Aix-Marseilles (France, 2004)

Received 2 March 2006, Accepted 25 September 2006

\section{References}

Andersson, T. and Swensson, R. (1996), "Entry Modes for Direct Investment Determined by the Composition of Firm-Specific Skills", Scandinavian Journal of Economics, vol. 4: pp.551-560.

Andrade, G., Mitchell, M. and Stafford, E. (2001), "New Evidence and Perspectives on Mergers", Journal of Economic Perspectives, vol. 15 n 2: pp. 103-120.

Baldwin, J. and Gorecki, P. (1987), "Plant Creation Versus Plant Acquisition : The Entry

Process in Canadian Manufacturing", International Journal of Industrial Organization, vol. 5: pp. 27-41.

Basile, R. (2004), “Acquisition versus Greenfield Investment : The location of foreign manufacturers in Italy", Regional Science and Urban Economics, vol. 34 no 1: pp. 3-25.

Bertrand, O. (2005), "On the Effects of Economic Integration on Greenfield Investments and Cross-border M\&A Location Pattern”, Journal of Economic Integration, Vol. 20 $\mathrm{n}^{\circ} 1$

Bjorvatn, K. (2001), "On the profitability of cross-border mergers", Norwegian School of Economics and Business Administration, mimeo.

Black, B. (2000), “Is This the First International Merger Wave?", M\&A Lawyer, vol. 4 no 4: pp. 20-26.

Blonigen, B. A., Davis, R. B. and Head, K. (2003), "Estimating The Knowledge-Capital Model of The Multinational Enterprise : Comment", American Economic Review, vol. $93 \mathrm{n}^{\circ}$ 3: pp. $980-994$. 
Bris, A. and Cabolis, C. (2002), "Adopting Better Corporate Governance : Evidence from Cross-Border Mergers'", Yale School of Management, mimeo.

Cameron, A. and Trivedi, P. (1998), Regression Analysis of Count Data, Cambridge UK : Cambridge University Press.

Caves, R. E. (1991), Corporate Mergers in International Economic Integration, In A. Giovannini \& C. Mayer (Eds.) : European Financial Integration. Cambridge : Cambridge University Press, pp. 136-160.

Caves, R. E. (1996), Multinational Enterprise and Economic Analysis, Cambridge University Press, Cambridge.

Caves, R. E. and Mehra, S. (1986), Entry of Foreign Multinationals into U.S. Manufacturing Industries, In R. Porter (Eds.) : Competition in Global Industries. Harvard Business School Press.

Chapman, K. (2003), "Cross-border mergers/acquisitions : A review and research agenda", Journal of Economic Geography, vol. 3: pp. 309-334.

Crozet, M., Mayer, T. and Mucchielli, J.-L. (2004), "How do Firms Agglomerate? A Study of FDI in France", Regional Science and Urban Economics, vol. 34 no 1: pp. 27-54.

Devreux, M. P. and Griffith, R. (1998), "Taxes and the location of production : Evidence from a panel of US multinationals", Journal of Public Economics, vol. 68 no 3: pp. 335-367.

Di Giovanni, J. (2005), "What Drives Capital Flows? The Case of Cross-border M\&A Activity and Financial Deepening", Journal of International Economics, vol. 65 no 1: pp. 127-149.

Evenett, S. (2002), "The Cross-border Mergers and Acquisitions Wave of The Late 1990s", mimeo.

Fauli-Oller, R. (2000), "Takeover Waves", Journal of Economics and Management Strategy, vol. 9 n ${ }^{\circ}$ : pp. 189-210.

Ferrer, C. (1998), Patterns and Determinants of Location Decisions by French Multinationals in European Regions, In J.-L. Mucchielli (Ed) : Multinational Location Strategy : Economics, Geography, Management and Policy, JAI Press, Greenwich, Connecticut.

Fujita, M., Krugman, P. and Venables, A. (1999), “The Spatial Economy : Cities, Regions and International Trade", London School of Economics.

Girma, S. (2002), "The Process of European Integration and The determinants of Entry by non EU Multinationals in UK Manufacturing”, The Manchester School, vol. 70: pp. 315-335.

Gonzalez, P., Vasconcellos, G. M. and Kish, R. J. (1998), "Cross-Border Mergers and Acquisitions : The Undervaluation Hypothesis", Quarterly Review of Economics and Finance, vol. 38 n $^{\circ}$ 1: pp. 25-45.

Greene, W. H. (1994), "Accounting for excess zeros and sample selection in Poisson and binomial regression models", Working paper No. EC-94-10. New York University.

Görg, H. (2000), “Analysing Foreign Market Entry : The choice between Greenfield 
investment and Acquisitions", Journal of Economic Studies, vol. 27 no 3: pp. 168-181. Grossman, S. and Hart, O. (1980), "Takeover bids, the free rider problem, and the theory of the corporation", Bell Journal of Economics, vol. 11: pp. 42-64.

Guimarães, P., Woodward, D. and Figueiredo, O. (2000), "Agglomeration and the Location of Foreign Direct Investment in Portugal", Journal of Urban Economics, vol. 47 no 1: pp. 115-135.

Guimarães, P., Woodward, D. and Figueiredo, O. (2003), "A tractable approach to the firm location decision”, Review of Economics and Statistics, vol. 85 no 1: pp. 201-204.

Hart, O. (1995), "Corporate governance : Some theory and implications", The Economic Journal, vol. 105: pp. 678-689.

Hausman, J., Hall, B. and Griliches, Z. (1984), "Econometric models for Count data with an application to the patents-R\&D relationship", Econometrica, vol. $52 \mathrm{n}^{\circ}$ 4: pp. 909-938.

Head, K. and Mayer, T. (2004), The Empirics of Agglomeration and Trade, In V. Henderson \& J.F. Thisse (Eds.) Handbook of Regional and Urban Economics, Elsevier, vol. 4.

Head, K. and Ries, J. (1996), "Inter-city Competition for Foreign Investment : Static and

Dynamic effects of China's Incentive Areas", Journal of Urban Economics, vol. 40 no 1: pp. 38-60.

Head, K., Ries, J. and Swenson, D. (1995), "Agglomeration Benefits and Location Choice : Evidence from Japanese Manufacturing Investments in the United States", Journal of International Economics, vol. 38 n 3-4: pp. 223-247.

Healy, P. and Palepu, K. (1994), International corporate equity acquisitions : Who, where, and why?, In K. Froot (Eds.) Foreign Direct Investment, The University of Chicago Press.

Helpman, E. (1984), "A Simple Theory of Trade with Multinational Corporations", Journal of Political Economy, vol. 92 no 3: pp. 451-471.

Henderson, V. (1996), "Effects of Air Quality Regulation", American Economic Review, vol. 86: pp. 789-814.

Hennart, J.-F. and Park, Y.-R. (1993), "Greenfield vs Acquisition : The Strategy of Japanese Investors in the United States", Management Science, vol. $39 \mathrm{n}^{\circ}$ 9: pp. 1054-1070.

Hofstede, G. (1983), "The cultural relativity of organizational practices and theories", Journal of International Business Studies, vol. 14: pp. 75-89.

Horn, H. and Persson, L. (2001), "The Equilibrium Ownership of an International Oligopoly", Journal of International Economics, vol. 53: pp. 307-333.

Horstmann, I. J. and Markusen, J. R. (1992), "Endogenous market structures in international trade (natura facit saltum)", Journal of International Economics, vol. 32 no 1-2: pp. 109-129.

Kang, N. and Johansson, S. (2000), "Cross-border Mergers and Acquisitions : Their Role in Industrial Globalisation", OECD Working Papers, STI Working Papers 2000/1, vol. $8 \mathrm{n}^{\circ} 30$.

Kish, R. J. and Vasconcellos, G. M. (1993), “An Empirical Analysis of Factors Affecting 
Cross-Border Acquisitions : U.S.-Japan”, Management International Review, vol. 33 $n^{\circ} 3$ : pp. 227-245.

Knickerbocker, F. (1973), Oligopolistic Reaction and Multinational Enterprise, Harvard University Press, Cambridge MA.

La Porta, R., Lopez-De-Silanes, F., Shleifer, A. and Vishny, R. W. (1998), Law and Finance, Journal of Political Economy, vol. 101: pp. 678-709.

La Porta, R., Lopez-De-Silanes, F. and Shleifer, A. (1999), "Corporate ownership around the world", Journal of Finance, vol. 54: pp. 471-517.

Lambert, D. (1992), "Zero-inflated Poisson regression, with an application to defects in manufacturing", Technometrics, vol. 34: pp. 1-14.

List, J. (2001), "US county-level determinants of inbound FDI : Evidence from a two-step modified count data model", International Journal of Industrial Organization, vol. 19 no 6: pp. 953-973.

Louri, H. (2001), "Entry Through Acquisition : Determinants of Multinational Firm Choices", Review of Industrial Organization, no 19: pp. 199-209.

Mahboobi, L. (2002), "Recent privatisation trends in OECD countries", OECD, Corporate Affairs Division, mimeo.

Markusen, J. R. (1997), “Trade versus Investment Liberalization”, NBER Working Paper 6231.

Markusen, J. R. and Maskus, K. E. (1999,b), "Discriminating Among Alternative Theories of the Multinational Enterprise", NBER Working Paper 7164.

Markusen, J. R. and Maskus, K. E. (2002), "Discriminating Among Alternative Theories of the Multinational Enterprise", Review of International Economics, vol. 10 no 4.

Markusen, J. R. and Venables, A. J. (1988), "Trade policy with increasing returns and imperfect competition : Contradictory results from competing assumptions", Journal of International Economics, vol. 24 no 3-4: p. 299-316.

Mayer, T. and Mucchielli, J.-L. (2002), Hierarchical Location Choice and Multinational Firms' Strategy : A Nested Logit Model Applied to Japanese Investment in Europe, in Dunning J. and J-L. Mucchielli (Eds.), Multinational Firms, The Global and Local Dilemma, London : Routledge.

McFadden, D. (1984), "Econometric Analysis of Qualitative Response Models", In Z. Griliches \& M.D. Intriligator (Eds.) : Handbook of Econometrics, Amsterdam, Elsevier/ North-Holland, vol. 2.

Morosini, P., Shane, S. and Singh, H. (1998), "National cultural distance and cross-border acquisition performance", Journal of International Business Studies, vol. 29 no 1: pp. 137-158.

Neary, P. (2001), "Of Hype and Hyperbola : Introducing the New Economic Geography", Journal of Economic Literature, vol. 39: pp. 536-561.

Neary, P. (2004), "Cross-border mergers as instruments of comparative advantage", University College Dublin, mimeo.

Norback, P. and Persson, L. (2002), "Cross-Border Acquisitions and Greenfield entry", The Research Institute of Industrial Economics, Working Paper 570. 
Norback, P. and Persson, L. (2003), "Investment liberalization - why a restrictive crossborder merger policy can be counterproductive", mimeo.

OECD (2001), New Patterns of Industrial Globalisation Cross-border Mergers and Acquisitions and Strategic Alliances, Organisation for Economic Co-operation and Development, Paris.

Ó Huallachain, B. and Reid, N. (1997), "Acquisition versus Greenfield Investment : The Location and Growth of Japanese Manufacturers in the United States", Regional Studies, vol. 31 no 4: pp. 403-416.

Rossi, S. and Volpin, P. (2003), "Cross-Country Determinants of Mergers and Acquisitions", CEPR Discussion Paper 3889.

Schenk (1996), "Bandwagon Mergers, International Competitiveness, and Government Policy", Empirica, vol. 23 no 3: pp. 255-278.

Scherer, F. and Ross, D. (1990), Industrial Market Structure and Economic Performance, Houghton Mifflin.

Seth, A., Song, K. P. and Pettit, R. (2000), "Synergy, Managerialism or Hurbis? An Empirical Examination of Motives for Foreign Acquisitions of U.S. Firms", Journal of International Business Studies, vol. 31 no 3: pp. 387-405.

Smith, D. and Florida, R. (1994), "Agglomeration and Industrial location : An Econometric Analysis of Japanese-Affiliated Manufacturing Establishments in Automotive-Related Industries", Journal of Urban Economics, vol. 36: pp. 23-41.

UNCTAD (2000), World Investment Report : Cross-Border Mergers and Acquisitions and Development, United Nations. New York \& Geneva.

UNCTAD (2003), World Investment Report : FDI Policies for Development : National and International Perspectives, United Nations. New York \& Geneva.

Woodward, D. (1992), "Location Determinants of Japanese Manufacturing Star-Ups in the United States", Southern Economic Journal, vol. 58 no 3: pp. 690-708.

Zejan, M. (1990), "New Ventures or Acquisitions : The choice of Swedish Multinational Enterprises", Journal of Industrial Economics, vol. 38 no 3: pp. 349-355.

Zhang, K. H. and Markusen, J. R. (1999), "Vertical multinationals and host-country characteristics", Journal of Development Economics, vol. 59 no 2: pp. 233-252. 